\begin{tabular}{|l|l|l||}
\hline \multicolumn{2}{|c|}{ PublisherInfo } \\
\hline \hline PublisherName & $:$ & BioMed Central \\
\hline \hline PublisherLocation & $:$ & London \\
\hline \hline PublisherImprintName & $:$ & BioMed Central \\
\hline \hline
\end{tabular}

\title{
Catalase extends mouse lifespan
}

\begin{tabular}{|l|l|l||}
\hline \multicolumn{2}{|c|}{ ArticleInfo } \\
\hline \hline ArticleID & $:$ & 5086 \\
\hline \hline ArticleDOI & $:$ & $10.1186 /$ gb-spotlight-20050506-03 \\
\hline \hline ArticleCitationID & $:$ & spotlight-20050506-03 \\
\hline \hline ArticleSequenceNumber & $:$ & 62 \\
\hline \hline ArticleCategory & $:$ & Research news \\
\hline ArticleFirstPage & $:$ & 1 \\
\hline \hline ArticleLastPage & $:$ & 3 \\
\hline \hline & & RegistrationDate : 2005-5-6 \\
\hline ArticleHistory & $:$ & OnlineDate \\
\hline \hline ArticleCopyright & $:$ & BioMed Central Ltd2005-5-6 \\
\hline \hline ArticleGrants & $:$ & \\
\hline \hline ArticleContext & $:$ & 130596611 \\
\hline \hline
\end{tabular}




\section{Don Monroe}

Email: freelance@DonMonroe.com

Mice engineered to produce high levels of the antioxidant catalase live significantly longer than their wildtype counterparts, according to a report published online by Sciencethis week. Researchers observed the largest lifespan extension when they targeted the catalase to mitochondria, which are thought to be the major cellular source of reactive oxygen species (ROS) such as hydrogen peroxide.

The results lend support to the free-radical theory of aging, which attributes many of the infirmities of old age to accumulated cellular damage caused by ROS and the free radicals they generate. Although such damage increases with age, previous attempts to manipulate it have yielded contradictory results. "Until this study, it wasn't clear that it was truly a cause [of aging in mammals] or an effect that correlated with age," David Sinclair of Harvard Medical School, Boston, who was not involved in the study, told The Scientist. "It's a pretty big deal," he added.

Peter Rabinovitch, of the University of Washington, Seattle, and his team created transgenic mice that overexpressed human catalase. This enzyme is usually found in the peroxisome, where it breaks down hydrogen peroxide produced during lipid metabolism. Unless it is neutralized, hydrogen peroxide can go on to generate free radicals.

The researchers also incorporated short peptide sequences that marked the catalase for uptake by the peroxisome, by the nucleus, or by mitochondria. They verified that the mice with a mitochondrial target, referred to as MCAT, expressed large amounts of human catalase in heart and skeletal muscle. The median lifespan of these MCAT mice was about $20 \%$ longer than that of wildtype mice, a modest but highly significant increase. Catalase targeting the nucleus and peroxisome had little effect.

In addition to longer lives, the MCAT mice had fewer pathological changes in their hearts, lower levels of hydrogen peroxide, and less damage to nuclear DNA. In addition, the MCAT mice showed fewer DNA fragments resulting from mitochondrial deletions and were less susceptible to peroxideinduced inactivation of aconitase, which is a key enzyme in the Krebs Cycle. Some researchers believe that damage to these mitochondrial components leads to a vicious cycle, as the disrupted metabolic pathway generates even higher levels of ROS.

Rabinovitch said that the new results don't say for sure whether the protective effect arises because the free radicals are made in the mitochondrion or because mitochondria are more sensitive, or both. Still, Toren Finkel of the National Heart, Lung, and Blood Institute, who did not participate in the research, told The Scientist that lifetime extension by antioxidants is a straightforward prediction of whose validation has been long awaited. "It's the most direct, testable proof of the free-radical theory," he said.

In spite of its importance, the research provides little direct support for the use of dietary or pharmaceutical antioxidants, since the catalase is only effective at a specific location within the cell. Rabinovitch also noted that catalase was unevenly expressed among tissues, and even among individual cells within each tissue. With further research, he said, the lifespan enhancement might be made even larger.

Indeed, larger lifespan extensions have already been seen in mice, for example, in response to caloric restriction. Researchers like Sinclair suspect that oxidative stress is just one of a several mechanisms that 
lead to aging, all of which may be controlled by a common signalling pathway, such as the one involving SIR2.

Leonard Guarente, who studies SIR2 at the Massachussetts Institute of Technolgy, said that he was "surprised that it worked," but that the method used by Rabinovitch was "a good demonstration that fixing a cause can have an effect on a mammal."

"My hunch would be you could get even a larger effect by harnessing the effect of [calorie restriction]," Guarente told The Scientist.

Rabinovitch considers the relation among the various mechanisms as an open question. "Proponents of the free-radical theory can come up with explanations for a very broad spectrum" of age-related problems, he said, including DNA damage, cancer, and diseases like Alzheimer's.

\section{References}

1. S.E. Schriner et al., "Extension of murine lifespan by overexpression of catalase targeted to mitochondria," Science, May 6, 2005., [http://www.sciencemag.org]

2. David A. Sinclair, [http://www.hms.harvard.edu/dms/bbs/fac/sinclair.html]

3. Peter Rabinovitch, [http://www.pathology.washington.edu/research/labs/rabinovitch/]

4. The Peroxisome Website, [http://www.peroxisome.org/]

5. Toren Finkel, [http://ugsp.info.nih.gov/mentors/FINKEL.HTM]

6. G. Flores, "Fast track to longevity," The Scientist, March 7, 2005., [http://www.the-scientist.com/ news/20050307/01]

7. L.P. Guarente, "Forestalling the Great Beyond with the help of SIR2," The Scientist, April 26, 2004., [http://www.the-scientist.com/2004/4/26/34/1] 